\title{
INTRODUCTION TO SYMPOSIUM ON FRAMING GLOBAL MIGRATION LAW - PART III
}

\author{
Jaya Ramji-Nogales* and Peter J. Spiro ${ }^{\dagger}$
}

Part I of this symposium on framing global migration law introduced broad conceptual parameters of a new field, looking back to its international law roots and forward to a new orientation beyond the strictures of refugee law. Part II looked to situate global migration law along a range of theoretical dimensions. Part III closes out the symposium with contributions that offer a spectrum of critical perspectives on global migration law, suggesting directions in which the field might grow in the future.

Joel Trachtman suggests that separating out migration law could impede linkages with fields of international law that could facilitate the project of liberalizing migration. ${ }^{1}$ His essay focuses in particular on the relationship between labor migration and economic globalization, but the critique extends beyond those fields. While the aim of global migration law is to assemble the various fields of international law that implicate human mobility, Trachtman encourages global migration law scholars to remain alert to other fields of international law that will continue to impact migration dynamics.

Ralph Wilde also provides a critical perspective, reminding scholars of global migration law to learn from the errors of international human rights law. ${ }^{2}$ His essay recounts narratives of false progress and unintended consequences that have resulted from human rights initiatives in other contexts. Wilde's case study examines the situation of migrants under EU and international law, posing the possible costs of extending protections to migrants on an extraterritorial basis.

Audrey Macklin takes on the canon of global migration law, asking how old canonical cases should be treated in this new field. ${ }^{3}$ She suggests three ways of thinking about the canon: as history, situated in context without ongoing relevance; as a normative baseline, abstracted to a theoretical position; or as legal precedent. Macklin's essay uses this lens to explore perhaps the most notable migration-related decision by an international tribunal, the ICJ's 1954 Nottebohm case. Though global migration law is relatively thin on precedent, her piece offers an important reminder that the theoretical foundations of the field must include rigorous engagement with what came before.

Siobhán Mullally argues for a feminist/intersectional perspective on the field of global migration law. ${ }^{4}$ Focusing on rights claims by migrant domestic workers, she concludes that the field's transformative potential requires both challenging and working within the sovereignty-based global legal order that places migrants at its margins. Progress will require sustained efforts to give greater political visibility to the intersectionality of discrimination based on gender, race, and migration status.

\footnotetext{
* Associate Dean for Academic Affairs and I. Herman Stern Research Professor at Temple University Beasley School of Law.

† Charles R. Weiner Professor of Law at Temple University Beasley School of Law.

${ }^{1}$ Joel P. Trachtman, Is Migration a Coherent Field of International Law? The Example of Labor Migration, 111 AJIL UnBound 481 (2018).

${ }^{2}$ Ralph Wilde, The Unintended Consequences of Expanding Migrant Rights Protections, 111 AJIL Unbound 487 (2018).

${ }^{3}$ Audrey Macklin, Is it time to retire Nottebohm?, 111 AJIL Unbound 492 (2018).

${ }^{4}$ Siobhán Mullaly, Migrant Domestic Workers and Continuums of Exploitation: Beyond the Limits of Antitrafficking Laws, 111 AJIL UNBOUND 498 (2018).
}

\footnotetext{
The American Society of International Law, Jaya Ramji-Nogales and Peter J. Spiro $\odot$ 2018. This is an Open Access article, distributed under the terms of the Creative Commons Attribution licence (http://creativecommons.org/licenses/by/4.0/), which permits unrestricted re-use, distribution, and reproduction in any medium, provided the original work is properly cited.
} 
Chantal Thomas advocates for a postcolonial perspective on the field of global migration law, highlighting the need to convene international legal regimes that would not otherwise be in relationship with one another. ${ }^{5}$ Thomas argues that contemporary supranational law relating to migration and irregular migrants is characterized by substantive fragmentation, economic asymmetry, and presumptive exclusion. Without direction from international law, postcolonial states have tended towards exclusionary regimes, even as the history offers other possibilities.

Iris Goldner Lang demonstrates the field's commitment to encompassing all levels of the law, considering the complex interplay of international, EU and member state law in the context of migration, and exploring their relationship with four categories of migrants. ${ }^{6}$ She explores the ways in which large refugee inflows have tested the system, elevating national interests over international human rights commitments and EU obligations. This strategic deployment of different laws in response to migrant inflows suggests another cautionary tale for scholars of global migration law.

Finally, Moria Paz points us to the realities of human mobility: how mobility operates on the ground and how rights that regulate that mobility actually work in practice. ${ }^{7}$ Her essay interrogates sovereignty's challenge to human rights law relating to migrants. She sees the promise of a new field that might protect categories of migrants that fall through the gaps in refugee and human rights laws created by sovereign rules of territorial responsibility.

These essays look to stimulate the development of global migration law at the same time that they deliver cautionary perspectives on the new field. In the face of populist antiglobalist movements that draw strength from xenophobic rhetoric, laws, and policies targeting migrants, there is an urgent need to rigorously and critically examine global legal frameworks governing migration. This symposium represents a first step towards establishing a new field of global migration law which more holistically addresses the challenges and opportunities of global mobility.

${ }^{5}$ Chantal Thomas, Mapping Global Migration Law, or the Two Batavias, 111 AJIL Unbound 504 (2018).

${ }^{6}$ Iris Goldner Lang, The European Union and Migration: An Interplay of National, Regional, and International Law, 111 AJIL UNBOUND 509 (2018).

${ }^{7}$ Moria Paz, The Incomplete Right to Freedom of Movement, 111 AJIL Unbound 514 (2018). 